\title{
Article \\ A Study on the Efficiency of Sustainable Wine Grape Vineyard Management Strategies
}

\author{
Rita Perria ${ }^{1, *(1)}$, Alice Ciofini ${ }^{1}$, William Antonio Petrucci ${ }^{1}$, Mauro Eugenio Maria D'Arcangelo ${ }^{1}$, Paolo Valentini ${ }^{1}$, \\ Paolo Storchi ${ }^{1}$ (D) Giuseppe Carella ${ }^{2}$, Andrea Pacetti ${ }^{2}\left[\right.$ and Laura Mugnai ${ }^{2} \mathbb{C}$ \\ 1 Council for Agricultural Research and Economics, Research Centre for Viticulture and Enology, Viale Santa \\ Margherita 80, 52100 Arezzo, Italy; alice.ciofini@gmail.com (A.C.); \\ williamantonio.petrucci@crea.gov.it (W.A.P.); mauro.darcangelo@crea.gov.it (M.E.M.D.); \\ paolo.valentini@crea.gov.it (P.V.); paolo.storchi@crea.gov.it (P.S.) \\ 2 Department of Agriculture, Food, Environment and Forestry (DAGRI), Section Plant Pathology and \\ Entomology, University of Florence, Piazzale delle Cascine 28, 50144 Florence, Italy; \\ giuseppe.carella@unifi.it (G.C.); andrea.pacetti@unifi.it (A.P.); laura.mugnai@unifi.it (L.M.) \\ * Correspondence: rita.perria@crea.gov.it
}

check for updates

Citation: Perria, R.; Ciofini, A.; Petrucci, W.A.; D'Arcangelo, M.E.M.; Valentini, P.; Storchi, P.; Carella, G.; Pacetti, A.; Mugnai, L. A Study on the Efficiency of Sustainable Wine Grape Vineyard Management Strategies. Agronomy 2022, 12, 392. https://doi.org/10.3390/ agronomy12020392

Academic Editor: Alain Deloire

Received: 17 December 2021

Accepted: 31 January 2022

Published: 4 February 2022

Publisher's Note: MDPI stays neutral with regard to jurisdictional claims in published maps and institutional affiliations.

Copyright: (C) 2022 by the authors. Licensee MDPI, Basel, Switzerland. This article is an open access article distributed under the terms and conditions of the Creative Commons Attribution (CC BY) license (https:// creativecommons.org/licenses/by/ $4.0 /)$

\begin{abstract}
Crop protection strategies based on cupric products and mainly adopted in organic viticulture produce a consistent environmental impact due to the persistence of copper in soils and its negative effects on edaphic biodiversity. In this work, trials were carried out during the crop years 2018-2020 in a vineyard with an organic management by a low-copper strategy and in a conventional IPM management with an IPM strategy with reduced use of fungicides. Phytosanitary treatments have been strictly planned according to forecasting models, and fungicides have been partially substituted with substances improving the resistance mechanisms of plants. Different strategies of green manure management, in order to improve the health of vines, were also adopted. Results suggest the efficacy of the "GreenGrapes" plant protection strategy in conditions of low downy mildew pressure. Furthermore, no declines in the production quality have been recorded; conversely, the synergic effect of the green manure and the tested biostimulant substances ("GreenGrapes" protocols) and the green manure management improved yield and grape quality, compared with conventional conduction (IPM and Organic) with a grass covering.
\end{abstract}

Keywords: grapevine; Sangiovese; sustainability; plant protection

\section{Introduction}

Viticulture represents one of the more widespread and economically strategic agricultural sectors in the Mediterranean area [1]; however, cultivation methods cause a high environmental impact, mainly due to the large use of phytosanitary products required to prevent cryptogamic infections [2] often responsible for production losses and consequent economic damages for producers [3].

According to 2016 ISTAT (Istituto Nazionale di Statistica) data, 26\% of the total amount of fungicides distributed every year in the Italian agriculture is dispensed in the viticultural sector [4]. Therefore, in order to meet the increasing attention for the sustainability of agriculture, the implementation of innovative strategies to control vine fungal diseases is urgently necessary.

To date, cryptogamic diseases are mainly controlled with the use of copper and sulphur products [5], which are very effective to prevent downy mildew and powdery mildew, respectively, and represent up to the $70 \%$ of the total fungicide amount distributed in viticulture [4]. However, over the years, the large use of copper led to its over-accumulation in many vineyards soil, especially in soils with a high $\mathrm{pH}$, due to its high persistence in the topsoil layer [6-9]. Besides its importance as a micronutrient, an excessive concentration of copper, especially in bioavailable forms, can even exert phytotoxic effects on vines [10-13] 
and negatively influence the ecological balance of the vineyard [14]. Indeed, copper has been related to reduced vineyard fertility because of its impairing effects on nutrient cycles and biodiversity [15-20]. The use of copper in agriculture is strictly limited by current legislation (Regulation (EU) 2018/1981 of 13 December 2018). However, cupric fungicides represent the category of plant protection products most used in organic viticulture to combat downy mildew. [16,21-24].

On the other hand, Integrated Pest Management (IPM) viticulture, mandatory in the EU from 2014 after the adoption of the Sustainable Use of Pesticides Directive, is based on an innovative concept of agriculture, aimed to enhance the resilience capability of the vineyard, considered as an agroecosystem, and reduce the environmental impact of the crops. According to IPM principles, infections can be faced through multiple approaches [25] finalized to cut the use of synthetic fungicides (which use is allowed). Indeed, these products have been associated to negative effects on not-target organisms [26-29] and the development of fungicide resistance [5,30,31], as well as affecting the final products [32,33].

Therefore, in order to comply with the recent directive and improve viticulture sustainability, it is necessary to implement new approaches to protect vineyards from fungal diseases and examine their actual effectiveness. In this regard, some investigations reported evidence for the efficacy of natural substances, consisting of living microorganisms (biofungicides), bacterial derivatives, or botanicals, in contrasting pathogen attacks on grapevines [21,23,34-36]. However, their use is still limited, and commercial formulations have been scarcely developed. Biofungicides are known to exhibit different modes of action [37] such as pathogen parasitism, the production of toxic compounds, and competition for nutrients or space. Furthermore, some of these natural substances have been found to act as elicitors, reproducing the host-pathogen interactions and consequently stimulating the endogenous defence mechanisms of plants [25,36,38-43]. In particular, some evidence for their efficiency to control downy mildew infections has been obtained [44-47]. Other active molecules, known as biostimulants, can also contribute to the vine ability to resist to pathogens by enhancing their health status. Indeed, such substances can stimulate the physiological processes involved in the absorption and assimilation of nutrients, with an overall invigorating effect [48-51]. The mechanisms of action described above determined the choice of defense support products used in the protection strategies of the "GreenGrapes" protocols (here after GG) (Table 1). These protocols were set up in the trials carried out in the LIFE EU Life Green Grapes Project "New approaches for protection in a modern sustainable viticulture: from nursery to harvesting" on which the present paper was developed.

Table 1. Commercial products, doses and number of applications carried out during the threeyear trial, on each treatment: integrated pest management (IPM), IPM with reduced distribution of agrochemicals (IPM-GG), classic organic (ORG), and classic organic with reduced employment of copper and sulphur (ORG-GG).

\begin{tabular}{|c|c|c|c|c|c|c|c|c|}
\hline \multirow{2}{*}{ Active Ingredient } & \multirow{2}{*}{$\begin{array}{l}\text { Commercial } \\
\text { Product }\end{array}$} & \multirow{2}{*}{ Supplier } & \multirow{2}{*}{ Years } & \multicolumn{4}{|c|}{ Number of Applications for Treatment } & \multirow{2}{*}{$\frac{\text { Dose }}{\text { Kg-1 ha }}$} \\
\hline & & & & IPM & IPM-GG & ORG & ORG-GG & \\
\hline \multirow{3}{*}{ Dimetomorf, Metiram } & \multirow{3}{*}{ Forum top } & \multirow{3}{*}{$\begin{array}{l}\text { Basf Italia } \\
\text { S.p.a. }\end{array}$} & 2018 & 1 & 1 & & & 2.5 \\
\hline & & & 2019 & 3 & 3 & & & 2.5 \\
\hline & & & 2020 & 3 & 1 & & & 2.5 \\
\hline \multirow{3}{*}{ Fluopicolide, Fosetyl Al } & \multirow{3}{*}{$\begin{array}{l}\text { R6 Erresei } \\
\text { Albis }\end{array}$} & \multirow{3}{*}{ Bayer } & 2018 & 1 & 1 & & & 3 \\
\hline & & & 2019 & 2 & 1 & & & 3 \\
\hline & & & 2020 & 2 & 2 & & & 3 \\
\hline \multirow{3}{*}{$\begin{array}{c}\text { Cymoxanil. Fosetyl } \\
\text { Al, Copper }\end{array}$} & \multirow{3}{*}{$\begin{array}{l}\text { Vitene } \\
\text { triplo }\end{array}$} & \multirow{3}{*}{$\begin{array}{l}\text { Sipcam } \\
\text { Italia }\end{array}$} & 2018 & 1 & 1 & & & 4 \\
\hline & & & 2019 & 1 & & & & 4 \\
\hline & & & 2020 & 1 & & & & 4 \\
\hline
\end{tabular}


Table 1. Cont.

\begin{tabular}{|c|c|c|c|c|c|c|c|c|}
\hline \multirow{2}{*}{ Active Ingredient } & \multirow{2}{*}{$\begin{array}{l}\text { Commercial } \\
\text { Product }\end{array}$} & \multirow{2}{*}{ Supplier } & \multirow{2}{*}{ Years } & \multicolumn{4}{|c|}{ Number of Applications for Treatment } & \multirow{2}{*}{$\frac{\text { Dose }}{\text { Kg-1 ha }}$} \\
\hline & & & & IPM & IPM-GG & ORG & ORG-GG & \\
\hline \multirow{3}{*}{ Metalaxil, Copper } & \multirow{3}{*}{ Planet C } & \multirow{3}{*}{$\begin{array}{l}\text { Upl Europe } \\
\text { Ltd. }\end{array}$} & 2018 & 1 & 1 & & & \\
\hline & & & 2019 & 1 & 1 & & & 4 \\
\hline & & & 2020 & & & & & 4.5 \\
\hline \multirow{3}{*}{$\begin{array}{l}\text { Mandipropamid, } \\
\text { Zoxamide }\end{array}$} & \multirow{3}{*}{ Ampexio } & \multirow{3}{*}{$\begin{array}{l}\text { Syngenta } \\
\text { Italia }\end{array}$} & 2018 & 3 & & & & 0.5 \\
\hline & & & 2019 & 1 & 1 & & & 0.5 \\
\hline & & & 2020 & 1 & & & & 0.5 \\
\hline \multirow{3}{*}{$\begin{array}{l}\text { Copper (Bordeaux } \\
\text { mixture) }\end{array}$} & \multirow{3}{*}{$\begin{array}{l}\text { Bordoflow } \\
\text { new }\end{array}$} & \multirow{3}{*}{$\begin{array}{l}\text { Manica } \\
\text { S.p.a. }\end{array}$} & 2018 & 2 & & & & 3.5 \\
\hline & & & 2019 & 3 & 2 & 4 & 1 & 4 \\
\hline & & & 2020 & 1 & & & & 4 \\
\hline \multirow{3}{*}{ Tribasic copper sulphate } & \multirow{3}{*}{$\begin{array}{l}\text { Cuprofix } \\
\text { ultra } \\
\text { dispress }\end{array}$} & \multirow{3}{*}{$\begin{array}{l}\text { Upl Europe } \\
\text { Ltd. }\end{array}$} & 2018 & & $1(2.1) *$ & $10(1.7)$ & $10(1.3)$ & \\
\hline & & & 2019 & & & 7 & 5 & 1 \\
\hline & & & 2020 & $2(1.5)$ & $1(1.5)$ & $9(1)$ & $6(1)$ & \\
\hline Original blend of & \multirow{4}{*}{ Pur'apres } & \multirow{4}{*}{$\begin{array}{l}\text { Tailor'd } \\
\text { Wine } \\
\text { Design }\end{array}$} & 2018 & & 5 & & & 1.5 \\
\hline bioavailable nutrients (Mn. & & & 2019 & & 2 & & & 1.5 \\
\hline $\mathrm{Zn})$. Combination of & & & & & & & & \\
\hline $\begin{array}{l}\text { bacterial metabolites and } \\
\text { enzymatic compounds }\end{array}$ & & & 2020 & & 3 & & 1 & 1.5 \\
\hline \multirow{4}{*}{$\begin{array}{l}\text { Original blend of } \\
\text { bioavailable nutrients (Mn. } \\
\mathrm{Zn} \text { ). Combination of } \\
\text { bacterial metabolites and } \\
\text { enzymatic compounds }\end{array}$} & \multirow{4}{*}{ Pur'avant } & & 2018 & & & & 1 & 1 \\
\hline & & Tailor'd & 2019 & & & & & \\
\hline & & Wine & & & & & & \\
\hline & & Design & 2020 & & & & 2 & 1 \\
\hline \multirow{3}{*}{$\begin{array}{l}\text { Solid extract of alfalfa, } \\
\text { algae and molasses }\end{array}$} & K\&A & & 2018 & & & & 1 & 2.5 \\
\hline & Oomisine & Kalos & 2019 & & & & 1 & 2.5 \\
\hline & 2.0 & & 2020 & & & & 1 & 2.5 \\
\hline \multirow{3}{*}{$\begin{array}{l}\text { Solid extract of alfalfa, } \\
\text { algae and molasses }\end{array}$} & K\&A & & 2018 & & & & 2 & 2 \\
\hline & Evidence & Kalos & 2019 & & & & 1 & 2 \\
\hline & 2.0 & & 2020 & & & & 2 & 2 \\
\hline \multirow{4}{*}{$\begin{array}{l}\text { Fluid yeast extract } \\
\text { containing brown algae }\end{array}$} & K\&A & & 2018 & & 2 & & 2 & 0.75 \\
\hline & Frontiere & Kalos & 2019 & & & & 1 & 0.75 \\
\hline & 2.0 & & 2020 & & 2 & & 1 & 0.75 \\
\hline & & & 2018 & & 1 & & 2 & 2.5 \\
\hline Plant extracts & Dinamico & Fertenia & 2019 & & & & & \\
\hline & & & 2020 & & 2 & & 2 & 2.5 \\
\hline & & & 2018 & $1(2.5)$ & $5(3)$ & $1(2.5)$ & $1(3)$ & \\
\hline Zeolite & Zeolite & Fertenia & 2019 & $2(4.5)$ & $4(5.25)$ & $2(4.5)$ & $3(4)$ & \\
\hline & Fertenia & & 2020 & & 4 & 1 & 6 & 6 \\
\hline & & & 2018 & & 1 & & 1 & 1.6 \\
\hline Sweet orange oil & Prev'am & Nufarm & 2019 & & & & 2 & 1.6 \\
\hline & & & 2020 & & 1 & & 2 & 1.6 \\
\hline
\end{tabular}

${ }^{*}$ Bracket-reported values indicate the dose of application when it was not the same for all treatments.

To date, in order to aid a rational recourse to phytosanitary products, forecasting models and Decision Support Systems represent an effective strategy in both IPM and organic viticulture; essentially, those tools process climatic data in accordance with mathematical models identifying the conditions predisposing pathogen infections [52-54]. Consequently, relying on DSS systems helps producers to conduct phytosanitary treatments only if strictly necessary, and to select the most suitable commercial products to be used.

Besides the adverse effects caused using cupric fungicides, soil tillage and the excessive use of chemical fertilizers also contribute to soil erosion and degradation, whereas the recourse to alternative management methods, such as grass cover and green manure, represents a strategic solution for maintaining soil quality and health. Grass covers with periodical cuttings reduce soil erosion and nutrient leaching, especially in sloping vineyards, and alleviate soil compaction caused by mechanical operations, improve the habitat complexity, and thus increase the abundance and diversity of pathogen natural enemies that 
can exert a strong biological control [55,56]. Sowing different cover crops (green manure) that can finally be buried at the end of the season, on the other hand, allows for enrichment of the soil with organic matter [57-61].

In this work, we describe results obtained in three crop years (2018-2020) with different types of control management, following innovative strategies to reduce the use of synthetic/cupric phytosanitary products and to recover the resilience of the agroecosystem. The innovative defense strategies included using several commercial formulates, mainly classified as foliar fertilizers by the current legislation, based on natural substances known to elicit the natural systemic resistance mechanisms of plants against pathogens. In particular, the products employed belong to three main categories: seaweed extracts, plant extracts, and products containing enzymes and metabolites obtained from the biotechnological processing of the yeast Saccharomyces cerevisiae yeast; those substances will be classified as supporting substances.

Finally, the sustainability of each management was assessed by estimating their impact on both the human health and the environment.

\section{Materials and Methods}

\subsection{Experimental Site}

Trials were conducted over three years (2018-2020) in a vineyard, located in the Chianti Classico wine district $\left(43^{\circ} 37^{\prime} 42^{\prime \prime} \mathrm{N}, 11^{\circ} 15^{\prime} 38^{\prime \prime} \mathrm{E}\right.$; San Casciano, Firenze, Italy), on a $0.7 \mathrm{~m} \times 2.4 \mathrm{~m}$ spaced vineyard, characterized by a loamy-clay soil $(39.9 \%$ clay, $36.2 \%$ silt and $24.2 \%$ sand) cultivated with Sangiovese variety grafted on 110R rootstock, East-Westoriented, trained on an upward-vertical-shoot-positioned trellis, with spur cordon pruning, planted in 2011. Vines were pruned with eight buds per vine (two nodes per spur and four spurs per vine). The vineyard was subdivided into plots to apply the discrete management strategies foreseen in the project proposal and described below.

A meteorological station was installed close to the vineyard to monitor the climatic parameters and consequently plan phytosanitary treatments based on real infection risks. Indeed, data collected by the weather sensors were processed by the Vite.net ${ }^{\circledR}$ system, a Decision Support System (DSS) developed by Horta s.r.l., providing daily updated information aiding to carefully scheduling of the antifungal treatments.

\subsection{The "GreenGrapes" Strategies for the Vineyard Management}

Four types of crop protection management (henceforth referred to as protocols) were implemented in the vineyard: IPM (integrated pest management); IPM-GG (the classic IPM management characterized by a substantial reduction in fungicides distribution and by the use of supporting substances); ORG (organic management); ORG-GG (the organic management with a reduction in copper distribution, implementing supporting substances) (Table 1).

The commercial formulations were applied with a low-volume articulated sprayer (VMA Power 50) calibrated to deliver $3001 \mathrm{ha}^{-1}$, with a forward speed of $5.3 \mathrm{Km} / \mathrm{h}$ and an operating pressure of 1, $5 \mathrm{bar}$ and $2050 \mathrm{rpm}$. The applications of these treatments were performed based on the risk assessment given by the DSS.

The first phytosanitary treatments were applied between 23 and 27 April in all tested seasons, when the plants were at the phenological stage between the emission of the 5th and 6th leaf, and thus susceptible to the attack of the pathogen Plasmopara viticola, and continued until the infection risk was reported by the DSS.

The active substances adopted, the number of treatments applied, and the doses used are listed in Table 1; the last phytosanitary treatment was applied on 12 July, 13 July, and 10 July in the three years of the trial, respectively.

For each of the 4 treatment plots which covered an area of approximately 10,000 $\mathrm{m}^{2}$, a grass-covered sub-plot $(\mathrm{g})$ and a green-manured sub-plot $(\mathrm{m})$ were identified. For the former, the agronomical practices basically consisted of $2 / 3$ grass cutting operations. 
The green manured rows consisted in a cover crop mixture composed by species belonging to the botanical families Fabaceae, Graminaceae, Brassicaceae, and Hydrophyllaceae (Table 2) sowed in late autumn (October-November). Subsequently, in late spring (AprilMay), the inter-rows were subjected to disc harrow processing to plough the vegetation, and, after few weeks, to a weeding towel operation to promote the embedding of the crops to the soil (the last operation was repeated even during the summer).

Table 2. Composition of the cover crop mixture employed in the " $\mathrm{m}$ " (green manure) sub-plot rows.

\begin{tabular}{cc}
\hline Botanical Family & Species \\
\hline Fabaceae $(55 \%)$ & Vicia faba L. (30\%) \\
Vicia sativa L. $(10 \%)$ \\
Pisum sativum L. $(10 \%)$ \\
Trifolium incarnatum L. (5\%)
\end{tabular}

\subsection{Plant Disease Monitoring Activity and Evaluation of Infections}

During the three years of experimentation, the main diseases of the vine (downy mildew, powdery mildew, and gray mold) were monitored during the most susceptible phenological phases.

The treatments were carried out on an area of $40,000 \mathrm{~m}^{2}$, divided into 4 blocks of about $10,000 \mathrm{~m}^{2}$ each, homogeneous in terms of soil characteristics and environmental conditions.

Each of the 4 treatments underwent a different protection strategy.

The incidence (percentage of leaves/clusters affected by symptoms) and severity (percentage of leaf surface/cluster affected by symptoms) of diseases (downy mildew, powdery mildew, and gray mold) on 25 leaves and 25 clusters for 4 random replicates were evaluated in each block, at each sampling time (Table 3).

Table 3. Monitoring activity scheme of Plasmopara viticola infections for each trial year: organs, number of organs and phenological stage.

\begin{tabular}{cccccc}
\hline $\begin{array}{c}\text { Phenological } \\
\text { State }\end{array}$ & Organ & $\begin{array}{c}\text { Number of Organs } \\
\text { Monitored }\end{array}$ & $\mathbf{2 0 1 8}$ & $\mathbf{2 0 1 9}$ & $\mathbf{2 0 2 0}$ \\
\hline BBCH 107-109 & Leaves & 100 & 6-May & 7-May & 5-May \\
BBCH 110-113 & Leaves & 100 & 18-May & 15-may & 13-May \\
BBCH 57-69 & Leaves/Cluster & $100 / 100$ & 31-May & 30-May & 28-May \\
BBCH 65-73 & Leaves/Clusters & $100 / 100$ & 6-June & 7-June & 3-June \\
BBCH 72-77 & Leaves/Clusters & $100 / 100$ & 20-June & 19-June & 19-June \\
BBCH 79 & Leaves/Clusters & $100 / 100$ & 9-July & 5-July & 3-July \\
BBCH 85-89 & Leaves/Clusters & $100 / 100$ & 24-July & 28-July & 27-July \\
\hline
\end{tabular}

The severity of the disease was assessed, following the indications provided by the EPPO guidelines, based on the extension of the leaf or cluster area affected [62].

\subsection{Quality of Final Production and Vine Balance}

For each trial (defense protocol $X$ soil management), three inter-rows portions have been randomly selected in different sectors of the same row, excluding the terminal portions to avoid edge effects. In each inter-row, three consecutive plants were subjected to the sampling: the clusters were counted, manually picked, and weighted with a portable electronic scale. Grapevines were sampled in order to assess yield (kg/plant), clusters per plant $(n)$, cluster and berry weight $(\mathrm{g})$. Musts obtained were analyzed for TSS, $\mathrm{pH}$, 
Titratable acidity, total and extractable anthocyanins, and phenolic maturity. In the last two crop years, the Ravaz Index was also calculated, weighing the one-year-old pruning wood, sampled in December from the same vines previously subjected to harvest. The following instruments/methods were employed for must analysis: a digital refractometer (DBR 95, XS Instruments, Carpi, Italy); pH meter (micropH 2002, Crison Instruments, s.a., Alella, Spain). Three replicates, each one composed of 100 filtered randomly chosen berries were employed in order to assess TSS ( ${ }^{\circ}$ Brix), titratable acidity, organic acids, and phenolic maturity. Some drops of musts were poured on the digital refractometer in order to asses TSS; titratable acidity was calculated by acid-base titration of $10 \mathrm{~mL}$ of must with $0.1 \mathrm{~N} \mathrm{NaOH}$ and blue bromothymol used as an acid-base indicator at $\mathrm{pH}$ 7.0. Phenolic maturity (total and extractable anthocyanins) was assessed according to O.I.V. (International Organization of Vine and Wine) official methods (see Compendium of International Methods of Analyses-OIV-OENO 21/2004) by analyzing musts achieved from pressing and filtering 100 randomly chosen berries. Phenolic maturity was evaluated by following the partially modified method proposed by Glories [63].

\subsection{Sustainability of the Production Processes Assessment}

The sustainability of the production processes carried out in each crop year was evaluated individually for all the different protocols relying on Yousustain.net ${ }^{\circledR}$ (Available online: https:/ / www.horta-srl.it/yousustain-net/ (accessed on 26 February 2021), a tool implemented to quantify the sustainability, examining agronomic factors (such as soil erosion and water use efficiency), biodiversity-related aspects, risks for human health associated with the phytosanitary products used, and a LCA (Life Cycle Assessment) analysis. The software gave a response by different indicators (carbon footprint, human tox score, just to name a few), assembled on Compartments (health, air, water, soil, biodiversity and energy consumption). The less the Indicator or Compartment score, the more the sustainability.

\subsection{Stastistical Analysis}

Statistical analyses were carried out by using SPSS Statistics software (IBM SPSS Statistics V20, Chicago, IL, USA). Data were analyzed by a one-way ANOVA in order to evaluate the statistical relevance of differences between treatments. Mean values of protocols (IPM, IPM-GG, ORG, ORG-GG), years, soil conduction (g/m) were then separated by the Duncan multiple range post-hoc test. Differences were assumed as statistically significant for $p<0.05$.

\section{Results}

\subsection{Plant Diseases and Evaluation of Infection}

\subsubsection{Climate Data: 2018}

The crop year 2018 was characterized by numerous rainy events which were most concentrated in March (18 rainy events), April (8 rainy events), and May (14 rainy events), with a total of $374 \mathrm{~mm}$ of rain fallen between 1 March and 30 May (Figure 1B). According to the indications of the DSS and the data recorded with field monitoring, the plant, based on the $\mathrm{BBCH}$, was susceptible to the disease, starting from the last week of April. In June, there were three rain events for a total of $20 \mathrm{~mm}$ of rain; in July, there were four rain events and $26 \mathrm{~mm}$ of rain. In August, there were nine rainy days for a total of $88 \mathrm{~mm}$. In the same period, the average temperatures were above $24{ }^{\circ} \mathrm{C}$ for most days (Supplementary Table S1). The meteorological data clearly suggest that 2018 was a year of high disease pressure for downy mildew (Supplementary Table S1). 

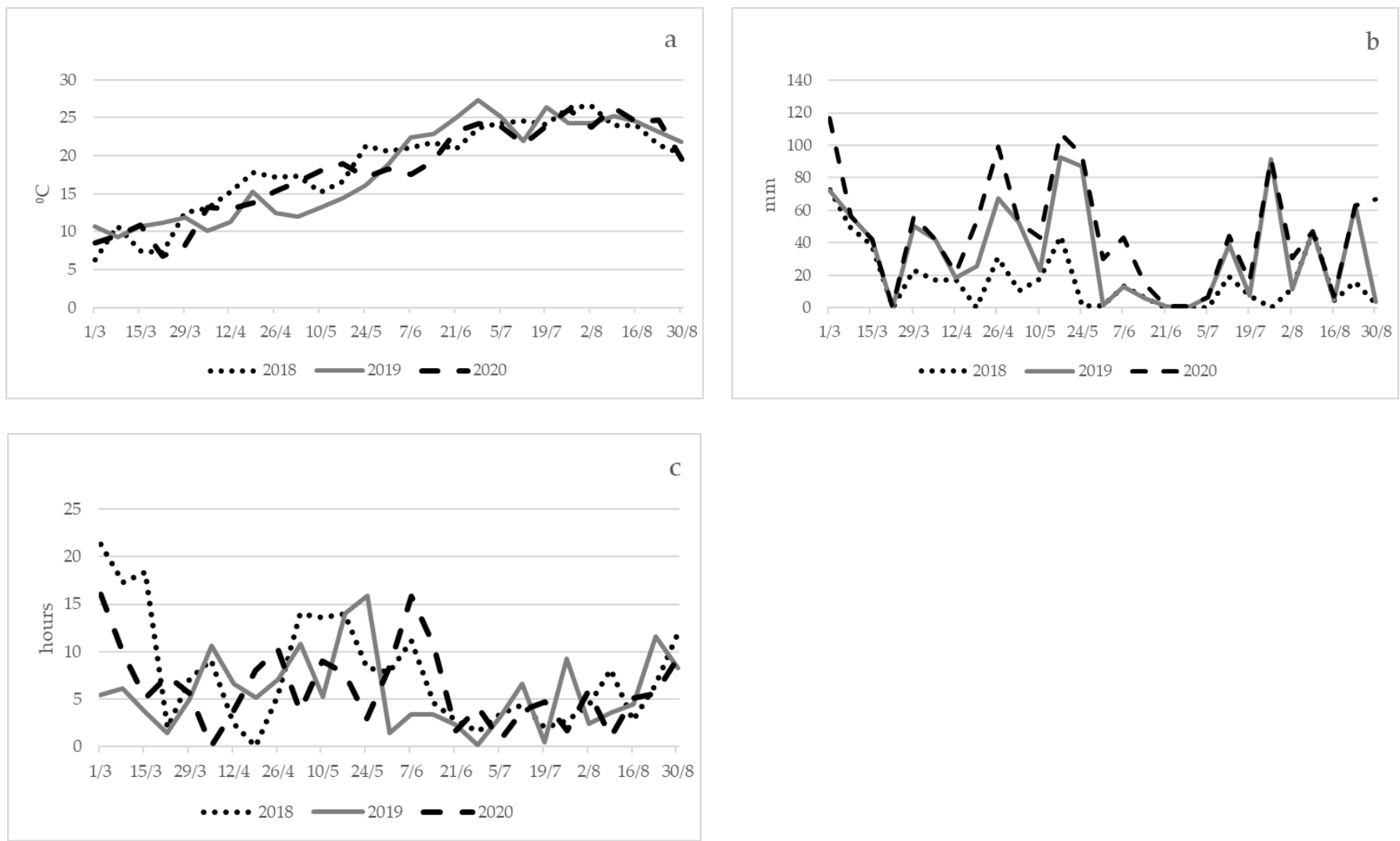

Figure 1. Comparison of the meteorological parameters for each year: average temperatures (a), $\mathrm{mm}$ of rain fallen $(\mathbf{b})$, hours of leaf wetness $(\mathbf{c})$, weekly gathered.

The analysis of the data deriving from the monitoring carried out both on the leaves and on the clusters (Table 3), highlighted statistically significant differences between the treatments (Table 4).

Table 4. Average percentage of incidence and severity of Plasmopara viticola calculated both on leaves and on bunches of the vineyards treated with the four control strategies: IPM; integrated pest management with pesticide reduction and supporting substances addition (IPM-GG); defense management in organic viticulture (ORG); disease control management adding supporting substances and copper reduction (ORG-GG). The data were subjected to univariate analysis (ANOVA): $p<0.05$. In each column, values followed by the same letter indicate homogeneous subgroups (Duncan test, $p<0.05)$.

\begin{tabular}{cccccc}
\hline Year & Treatment & $\begin{array}{c}\text { Leaf Incidence } \\
\mathbf{\%}\end{array}$ & $\begin{array}{c}\text { Leaf Severity } \\
\mathbf{\%}\end{array}$ & $\begin{array}{c}\text { Cluster } \\
\text { Incidence } \\
\%\end{array}$ & $\begin{array}{c}\text { Cluster } \\
\text { Severity } \\
\%\end{array}$ \\
\hline \multirow{2}{*}{2018} & IPM & $19.5 \pm 4.55 \mathrm{~b}$ & $1.79 \pm 0.98 \mathrm{~b}$ & $4.0 \pm 3.16 \mathrm{c}$ & $0.22 \pm 0.23 \mathrm{~b}$ \\
& ORG & $20.56 \pm 5.50 \mathrm{~b}$ & $2.32 \pm 0.47 \mathrm{~b}$ & $12.5 \pm 6.69 \mathrm{c}$ & $0.91 \pm 0.29 \mathrm{~b}$ \\
& IPM-GG & $43.47 \pm 8.5 \mathrm{a}$ & $3.74 \pm 0.99 \mathrm{ab}$ & $32.0 \pm 6.32 \mathrm{~b}$ & $4.05 \pm 1.97 \mathrm{a}$ \\
& ORG-GG & $45.50 \pm 10.23 \mathrm{a}$ & $4.94 \pm 1.83 \mathrm{a}$ & $53.5 \pm 20.15 \mathrm{a}$ & $5.20 \pm 2.26 \mathrm{a}$ \\
\hline \multirow{3}{*}{2019} & IPM & $3.0 \pm 1.0 \mathrm{a}$ & $0.075 \pm 0.02 \mathrm{~b}$ & 0.0 & 0.0 \\
& ORG & $2.0 \pm 2.0 \mathrm{a}$ & $0.325 \pm 0.33 \mathrm{~b}$ & 0.0 & 0.0 \\
& IPM-GG & $2.5 \pm 0.87 \mathrm{a}$ & $0.150 \pm 0.59 \mathrm{~b}$ & 0.0 & 0.0 \\
& ORG-GG & $3.5 \pm 0.93 \mathrm{~b}$ & $1.0 \pm 0.37 \mathrm{a}$ & 0.0 & 0.0 \\
\hline \multirow{2}{*}{2020} & IPM & $1.88 \pm 0.65 \mathrm{c}$ & $0.10 \pm 0.02 \mathrm{c}$ & $0.38 \pm 0.09 \mathrm{c}$ & $0.02 \pm 0.004 \mathrm{c}$ \\
& ORG & $24.75 \pm 1.80 \mathrm{~b}$ & $3.38 \pm 0.45 \mathrm{~b}$ & $6.88 \pm 1.24 \mathrm{~b}$ & $1.49 \pm 0.10 \mathrm{ab}$ \\
& IPM-GG & $22.75 \pm 4.87 \mathrm{~b}$ & $3.03 \pm 0.9 \mathrm{~b}$ & $5.75 \pm 1.30 \mathrm{~b}$ & $1.30 \pm 0.18 \mathrm{~b}$ \\
& ORG-GG & $61.75 \pm 2.50 \mathrm{a}$ & $9.13 \pm 1.65 \mathrm{a}$ & $41.40 \pm 5.63 \mathrm{a}$ & $17.98 \pm 1.44 \mathrm{a}$ \\
\hline
\end{tabular}


In 2018, the incidence of downy mildew on leaves was higher in the "GreenGrapes" treatments (IPM-GG and ORG-GG), which statistically belong to the same subset and differ from the company treatments (IPM and ORG). Statistical differences were also recorded on the clusters. In particular, ORG-GG showed the highest value of incidence and severity both on leaves and on bunches.

Figure 2 shows the trend in the incidence of the disease on leaves based on the monitoring carried out during the growth season.

\subsubsection{Climate Data: 2019}

The crop year 2019 was characterized by a rainy period between the beginning of April and the end of May. During these months, there were 27 rain events for a total of $271 \mathrm{~mm}$. The average weekly temperature in this period was around $13^{\circ} \mathrm{C}$; after only a few days, it exceeded $15^{\circ} \mathrm{C}$ (Supplementary Table S2).

The meteorological data of the three years of trials (Figure 1B) showed the differences that allowed us to better understand the evolution of the disease.

In 2019, compared with the other two years, a lower temperature was noted from mid-April to the end of May (Figure 1A). In the following period, from the end of May to the first week of July, there was a higher increase in temperatures. Between the middle and the end of May, a period of greater rain intensity (millimeters of rain fallen, Figure 2B) than in the other two years was recorded, and from the end of May-beginning of June to the end of June, the leaf wetness hours were lower than in the same period in 2018 and 2020 (Figure 2C).

During the 2019 season, there were no significant increases in the incidence of the disease, which remained very low until harvest (Figure 2B).

During the most intense rainy period, plants were in a phenological phase between the emission of the first leaf, recorded on 18 May, and the emission of the 12th leaf recorded on 31 May.

No statistically significant differences were recorded on the incidence and severity of downy mildew on the leaves (Table 4), both in treatments with or without copper and/or synthetic fungicides reduction.

No infections were recorded on the bunch in the 2019 season in any of the four treatments compared.

\subsubsection{Climate Data: 2020}

In 2020, the most intense rainy period was recorded between 10 May and 14 June (Figure 2B), during which 14 rain events occurred for a total of $108.6 \mathrm{~mm}$, with an average temperature for most days above $18{ }^{\circ} \mathrm{C}$ and leaf wetness (weekly average) mostly for 7 to $10 \mathrm{~h}$ a day (Figure $1 \mathrm{~A}-\mathrm{C}$, Supplementary Table S3).

From the second half of June to the end of August, only eight rainy days were recorded ( $99.9 \mathrm{~mm}$ rain). During the period of greatest rain intensity, the plant was in a phenological phase between the emission of the 9th leaf on 10 May and the pea-sized grape on 20 June.

In 2020, the incidence of downy mildew was reduced in the first part of the season in all the treatments considered, but it increased since the end of June in all the treatments except the ones with integrated management (Figure 2C), where the incidence remained low until harvest.

In 2020, the incidence of downy mildew both on leaves and on clusters showed the same differences between the company treatments (IPM and ORG) and the GreenGrapes treatments (IPM-GG and ORG-GG) (Table 4). ORG-GG protocol was the one with the highest and statistically different incidence. The IPM-GG and the ORG managements did not show statistically significant differences. The IPM protocol is the one where the lowest incidence of the disease was recorded both on bunches and leaves.

ORG-GG management showed the highest severity both on bunches and leaves and IPM showed the lowest, which was in line with the results obtained on the incidence. 
No statistically significant differences were recorded between the IPM-GG and the ORGGG protocols.

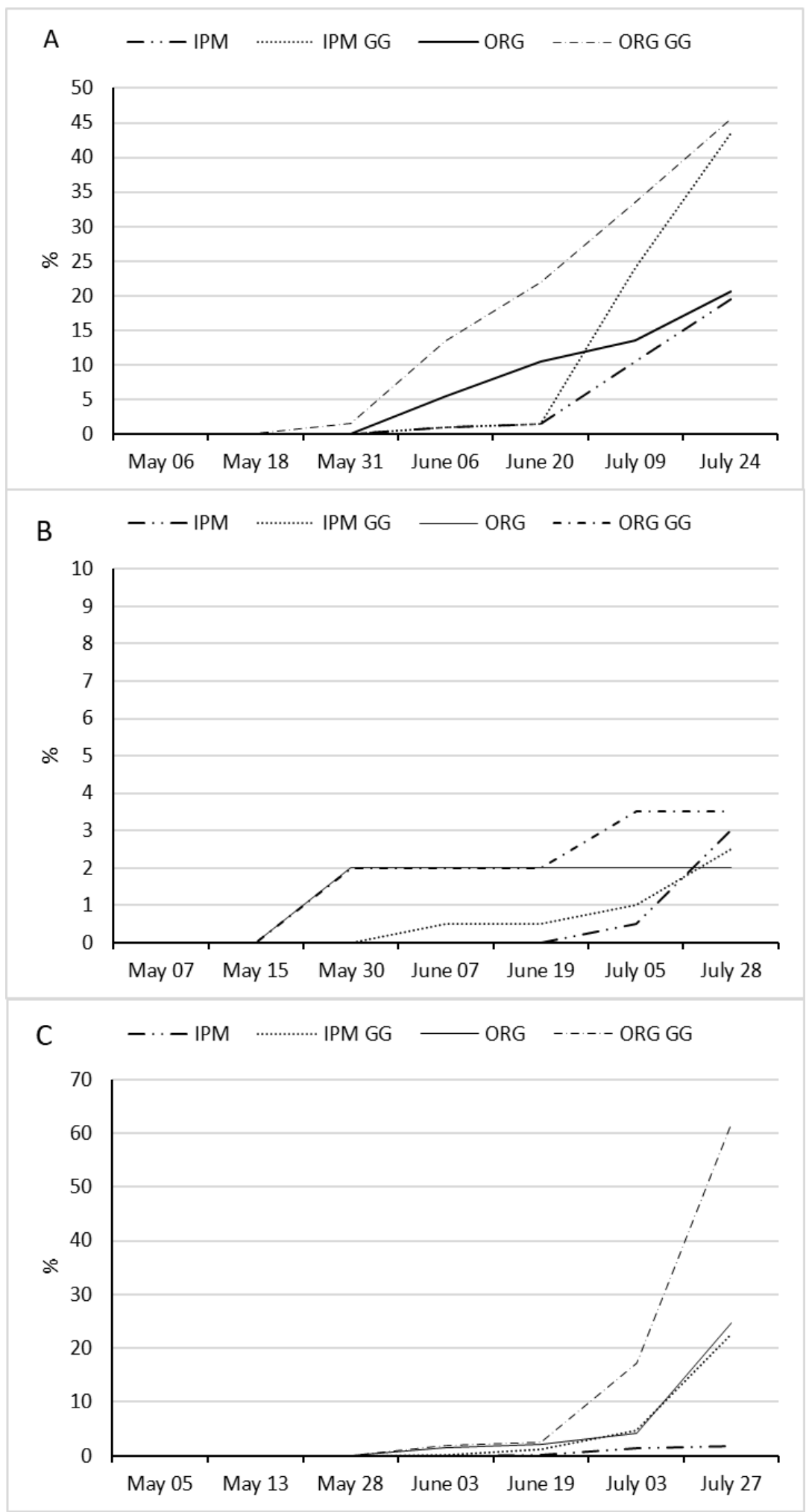

Figure 2. Incidence trend of downy mildew on leaves for the years 2018 (A), 2019 (B) and 2020 (C). for each trial: IPM; integrated pest management with pesticide reduction and supporting substances addition (IPM-GG); disease control management in organic viticulture (ORG); disease control management adding supporting substances and copper reduction (ORG-GG). 


\subsection{Quality of Final Production and Vine Balance}

\subsubsection{Soil Management}

Significant differences have been observed for mean yield and bunch weight (Table 5) where the trials conducted with green manure management gave a better performance. Regarding vine pruning, GG treatments positively affected wood production only in IPM managed with green manure (419.6 g/vine), whereas other trials showed no significant differences (from 275 to $332.5 \mathrm{~g} /$ plant) (Table 5); the difference appeared in the third year of management.

Table 5. Three years means production components: yield (Kg/vine), bunch weight (g), bunch number; pruning wood production (g/plant) and Ravaz index calculated for each Protection protocol $X$ soil (grass covering-g; green manure-m) management trial. Different letters show significant difference for $p<0.05$.

\begin{tabular}{ccccccc}
\hline $\begin{array}{c}\text { Protection } \\
\text { Protocol }\end{array}$ & $\begin{array}{c}\text { Soil } \\
\text { Management }\end{array}$ & Yield (Kg/vine) & $\begin{array}{c}\text { Bunch Weight } \\
\mathbf{( g )}\end{array}$ & $\begin{array}{c}\text { Bunch } \\
(\text { n/Plant) }\end{array}$ & $\begin{array}{c}\text { Wood Production } \\
\text { (g/Plant) }\end{array}$ & Ravaz Index \\
\hline \multirow{2}{*}{ IPM } & $\mathrm{g}$ & $1.3 \pm 0.5 \mathrm{a}, \mathrm{b}$ & $111.1 \pm 36.9 \mathrm{a}$ & $12 \pm 5.2 \mathrm{e}$ & $276.7 \pm 57.9 \mathrm{a}$ & $5.1 \pm 1.6 \mathrm{a}$ \\
& $\mathrm{m}$ & $1.6 \pm 0.7 \mathrm{c}$ & $154 \pm 37.3 \mathrm{~b}, \mathrm{c}$ & $10.9 \pm 4.7 \mathrm{~d}$ & $295.5 \pm 100.9 \mathrm{a}$ & $5.8 \pm 1.6 \mathrm{a}$ \\
\hline \multirow{2}{*}{ IPM-GG } & $\mathrm{g}$ & $1.1 \pm 0.5 \mathrm{a}$ & $130.7 \pm 36.8 \mathrm{a}, \mathrm{b}$ & $8.7 \pm 3.3 \mathrm{a}, \mathrm{b}$ & $282.5 \pm 112.6 \mathrm{a}$ & $5.8 \pm 19 \mathrm{a}$ \\
& $\mathrm{m}$ & $1.7 \pm 1 \mathrm{c}$ & $165.3 \pm 55.2 \mathrm{c}, \mathrm{d}$ & $10.1 \pm 4 \mathrm{c}, \mathrm{d}$ & $419.6 \pm 47.3 \mathrm{~b}$ & $4.1 \pm 2.3 \mathrm{a}$ \\
\hline \multirow{2}{*}{ ORG } & $\mathrm{g}$ & $1.5 \pm 0.6 \mathrm{~b}, \mathrm{c}$ & $183.1 \pm 57 \mathrm{~d}, \mathrm{e}$ & $8.5 \pm 2.8 \mathrm{a}, \mathrm{b}, \mathrm{c}$ & $277.3 \pm 33.6 \mathrm{a}$ & $4.4 \pm 17 \mathrm{a}$ \\
& $\mathrm{m}$ & $1.5 \pm 0.8 \mathrm{~b}, \mathrm{c}$ & $225.7 \pm 60.8 \mathrm{f}$ & $6.9 \pm 2.9 \mathrm{a}$ & $332.5 \pm 69.9 \mathrm{a}$ & $5.5 \pm 2.1 \mathrm{a}$ \\
\hline \multirow{2}{*}{ ORG-GG } & $\mathrm{g}$ & $1.2 \pm 0.5 \mathrm{a}$ & $155.4 \pm 37.1 \mathrm{~b}, \mathrm{c}$ & $7.2 \pm 2 \mathrm{a}, \mathrm{b}$ & $275 \pm 51.7 \mathrm{a}$ & $4.1 \pm 1.2 \mathrm{a}$ \\
& $\mathrm{m}$ & $1.7 \pm 0.6 \mathrm{c}$ & $195.9 \pm 61.7 \mathrm{e}$ & $8.9 \pm 2.8 \mathrm{~b}, \mathrm{c}$ & $317.3 \pm 33.6 \mathrm{a}$ & $5.6 \pm 1.7 \mathrm{a}$ \\
\hline
\end{tabular}

The performance of green manure or grass coverings did not reveal any significant difference within the same protocol over three years of TSS, titratable acidity, grape weight, bunch number per plant, organic acids (except for shikimic and citric, in the ORG management), total anthocyanins (except in the ORG management), or phenolic richness (except in the ORG management) (Table 6).

Table 6. Mean over three years means TSS, total acidity, total and extractable anthocyanins for each protection protocol X soil (grass covering-g; green manure-m) management trial. Different letters show significant difference for $p<0.05$.

\begin{tabular}{cccccc}
\hline $\begin{array}{c}\text { Defense } \\
\text { Protocol }\end{array}$ & $\begin{array}{c}\text { Soil } \\
\text { Conduction }\end{array}$ & TSS ( ${ }^{\circ}$ Brix) & TA (g/L) & $\begin{array}{c}\text { Total Anthocyanins } \\
\text { (mg/Kg (+)-Malvidin) }\end{array}$ & $\begin{array}{c}\text { Extractable Anthocyanins } \\
\text { (mg/Kg Catechin 3 Glucoside) }\end{array}$ \\
\hline \multirow{2}{*}{ ORG-GG } & $\mathrm{g}$ & $24.2 \pm 1.5 \mathrm{~b}$ & $5,6 \pm 0.5 \mathrm{a}, \mathrm{b}$ & $1542 \pm 271 \mathrm{a}, \mathrm{b}, \mathrm{c}$ & $754 \pm 158 \mathrm{a}, \mathrm{b}, \mathrm{c}$ \\
& $\mathrm{m}$ & $23.7 \pm 1.6 \mathrm{a}, \mathrm{b}$ & $5,5 \pm 0.4 \mathrm{a}, \mathrm{b}$ & $1430 \pm 262 \mathrm{a}, \mathrm{b}$ & $727 \pm 128 \mathrm{a}, \mathrm{b}$ \\
ORG & $\mathrm{g}$ & $23.9 \pm 0.9 \mathrm{a}, \mathrm{b}$ & $5,6 \pm 0.5 \mathrm{a}, \mathrm{b}$ & $1681 \pm 242 \mathrm{c}$ & $792 \pm 103 \mathrm{a}$ \\
& $\mathrm{m}$ & $23.7 \pm 0.8 \mathrm{a}, \mathrm{b}$ & $5,6 \pm 0.5 \mathrm{a}$ & $1386 \pm 225 \mathrm{a}$ & $707 \pm 141 \mathrm{a}, \mathrm{b}, \mathrm{c}$ \\
IPM-GG & $\mathrm{g}$ & $23.9 \pm 1.6 \mathrm{a}, \mathrm{b}$ & $5.9 \pm 0.7 \mathrm{a}, \mathrm{b}$ & $1655 \pm 243 \mathrm{~b}, \mathrm{c}$ & $847 \pm 167 \mathrm{c}$ \\
& $\mathrm{m}$ & $23.6 \pm 1.4 \mathrm{a}, \mathrm{b}$ & $5.8 \pm 0.5 \mathrm{a}, \mathrm{b}$ & $1576 \pm 285 \mathrm{a}, \mathrm{b}, \mathrm{c}$ & $761 \pm 172 \mathrm{a}, \mathrm{b}, \mathrm{c}$ \\
IPM & $\mathrm{g}$ & $23.9 \pm 1.3 \mathrm{a}, \mathrm{b}$ & $5.5 \pm 0.5 \mathrm{~b}$ & $1641 \pm 291 \mathrm{~b}, \mathrm{c}$ & $827 \pm 132 \mathrm{~b}, \mathrm{c}$ \\
& $\mathrm{m}$ & $23.0 \pm 2.2 \mathrm{a}$ & $5.7 \pm 0.6 \mathrm{a}, \mathrm{b}$ & $1532 \pm 247 \mathrm{a}, \mathrm{b}, \mathrm{c}$ & $793 \pm 168 \mathrm{a}, \mathrm{b}, \mathrm{c}$ \\
\hline
\end{tabular}

\subsubsection{Disease Control Management}

Application of GG treatments increased pruning wood production significantly only on IPM management (351.1 g/vine of IPM-GG against 286.1 of IPM), whereas no effect appeared on ORG management (respective means of $\mathrm{m} / \mathrm{g}$ in Table 5). The Ravaz index showed no significant differences inside all the trials.

The implementation of the GG management did not change the yield significantly (respective means of $\mathrm{m} / \mathrm{g}$ in Table 5) while negatively influencing the number of bunches per plant, whereas IPM obtained the best performance (11.5) and ORG the lowest (7.7). 
For the mean bunch weight, ORG management showed the heaviest (204.4 g) and IPM the lightest (132.6 g). ORG-GG showed grapevines with higher sizes (2.24 g) and IMP the lowest $(1.53 \mathrm{~g}$ ) (respective means of $\mathrm{m} / \mathrm{g}$ in Table 5). No significant differences were found for TSS (respective means of $\mathrm{m} / \mathrm{g}$ in Table 6), whereas for titratable acidity only IPM-GG $(5.8 \mathrm{~g} / \mathrm{L})$ showed a difference with respect to the other trials. The highest anthocyanins content derived from IPM-GG (1615.9), ORG-GG contained lower anthocyanins (1486.38) $(p<0.05)$; extractable anthocyanins were higher in IMP (810.61) and lower in ORG-GG $(p<0.05)$ (respective means of $\mathrm{m} / \mathrm{g}$ in Table 6$)$.

\subsection{Sustainability of the Production Processes}

Employment of GG protocols applied to IPM or GG allowed an important reduction in agrochemicals or copper distribution, fully answering to the need of a more sustainable production (Table 7).

Table 7. Mean reduction (\%) per year in antifungal active molecules in the IPM vineyard, and in copper and sulphur in the organic vineyard relating the "Green Grapes" (GG) defense protocol.

\begin{tabular}{ccccc}
\hline $\begin{array}{c}\text { Disease Control } \\
\text { Management }\end{array}$ & Active Molecule & $\begin{array}{c}\text { Farm } \\
\mathbf{( k g / h a )}\end{array}$ & $\begin{array}{c}\text { GG } \\
\mathbf{( k g / h a )}\end{array}$ & $\begin{array}{c}\text { Reduction } \\
\mathbf{( \% )}\end{array}$ \\
\hline \multirow{4}{*}{ IPM } & Ametoctradin & 0.09 & 0.00 & 100 \\
& Boscalid & 0.20 & 0.00 & 100 \\
& Cymoxanil & 0.14 & 0.07 & 47 \\
& Dimethomorph & 0.45 & 0.23 & 48 \\
& Fluopicolide & 0.22 & 0.13 & 39 \\
& Fosetyl-Al & 4.54 & 3.07 & 32 \\
& Mancozeb & 0.33 & 0.00 & 100 \\
& Mandipropamide & 0.12 & 0.04 & 64 \\
& Metiram & 2.55 & 1.83 & 28 \\
& Metrafenone & 0.20 & 0.11 & 46 \\
& Myclobutanil & 0.08 & 0.00 & 100 \\
& Copper oxychloride & 0.79 & 0.39 & 50 \\
& Quinoxyfen & 0.09 & 0.03 & 61 \\
& Copper sulphate & 2.22 & 0.88 & 60 \\
& Zoxamide & 0.12 & 0.04 & 66 \\
\hline ORGANIC & Copper & 5.2 & 3.9 & 25.1 \\
& Sulphur & 21.89 & 17.55 & 20 \\
\hline
\end{tabular}

Gathered data, once elaborated by Horta@, estimated the impact of the different production processes. The IPM management including green manure and grass covering) reached the highest Human tox index score, treatment frequency index, and Eco tox score, whereas for the same indicators, lower scores were reached by the application of GG protocols to IPM and ORG management (with green manure and grass coverings) (Table 8). ORG-GG with grass coverings and ORG with green manure reached the highest score for the carbon footprint indicator, whereas IPM with grass coverings and green manure reached the lowest. ORG and IPM-GG with grass covering and green manure, respectively, showed the highest score for carbon sequestration and grass-covered ORG/grass-covered ORG-GG (equally), and the lowest score for IPM (Table 8). For the water footprint, a major score was reached by grass-covered and green-manured ORG-GG, whereas IPM-GG showed the lowest point. Finally, green-covered and green-manured IPM-GG and ORG reached major scores; ORG and ORG-GG grass coverings and green manure reached the lowest point (Table 8). 
Table 8. Sustainability of each defense protocol x soil conduction (grass covering-g or green manure$\mathrm{m}$ ) relating the human tox score, treatment frequency index, eco tox score, carbon footprint, carbon sequestration and water footprint indicators; the more the value, the less the sustainability.

\begin{tabular}{|c|c|c|c|c|c|c|c|}
\hline $\begin{array}{c}\text { Disease } \\
\text { Control } \\
\text { Management }\end{array}$ & $\begin{array}{c}\text { Soil } \\
\text { Management }\end{array}$ & $\begin{array}{l}\text { Human } \\
\text { Tox Score }\end{array}$ & $\begin{array}{l}\text { Treatment } \\
\text { Frequency } \\
\text { Index }\end{array}$ & $\begin{array}{l}\text { Eco Tox } \\
\text { Score }\end{array}$ & $\begin{array}{c}\text { Carbon } \\
\text { Footprint } \\
\text { (t } \mathrm{CO}_{2} \text { eq/t of } \\
\text { Production) }\end{array}$ & $\begin{array}{c}\text { Carbon } \\
\text { Sequestration } \\
\text { ( } \mathrm{t} \text { of } \mathrm{C} / \mathrm{ha})\end{array}$ & $\begin{array}{c}\text { Water } \\
\text { footprint }\left(\mathrm{m}^{3}\right. \\
\text { of Water/t } \\
\text { Production) }\end{array}$ \\
\hline \multirow{2}{*}{ IPM } & $\mathrm{g}$ & 141.5 & 22.46 & 169.4 & 0.3 & 1.36 & 1419.67 \\
\hline & $\mathrm{m}$ & 141.57 & 22.46 & 169.43 & 0.28 & 1.54 & 1348.00 \\
\hline \multirow{2}{*}{ IPM-GG } & $\mathrm{g}$ & 107.83 & 16 & 114.73 & 0.34 & 1.25 & 1181.33 \\
\hline & $\mathrm{m}$ & 107.83 & 16 & 114.73 & 0.27 & 1.76 & 1021.00 \\
\hline \multirow{2}{*}{ ORG } & $\mathrm{g}$ & 63.83 & 21.8 & 39.83 & 0.31 & 1.45 & 1844.00 \\
\hline & $\mathrm{m}$ & 63.83 & 21.8 & 39.93 & 0.33 & 1.59 & 1839.33 \\
\hline \multirow{2}{*}{ ORG-GG } & $\mathrm{g}$ & 60.77 & 21.26 & 38.83 & 0.37 & 1.26 & 1769.33 \\
\hline & $\mathrm{m}$ & 61 & 21 & 38.83 & 0.28 & 1.61 & 1570.99 \\
\hline
\end{tabular}

\section{Discussion}

In order to reduce the amount of copper and fungicides used for downy mildew control, various alternative products and different control strategies were tested [18]. The trials allowed us to better understand which are the most suitable moments for the application of the products used to control the disease, and a mean substantial reduction in antifungal molecule distribution (Table 8).

This was possible thanks to the combined effect of the DSS [64] application and field monitoring that allowed us to record and process a large number of data, relating weather conditions, plant protection and plant support products sprays, disease pressure, and impact in the field of the strategies applied.

The correct use of DSS systems favors the reduction in pesticides and working hours, providing the winegrower with an economic profit [64]. The adoption of management strategies of the "GreenGrapes" vineyard guarantees greater environmental sustainability of viticulture and allows the producer to adequately address the growing limits to the use of pesticides imposed by the legislator. Copper, for example, a candidate molecule for replacement but currently essential for disease control especially in organic farming, has been reduced in the "GreenGrapes" protocols compared with the maximum quantity allowed by the Implementing Regulation (EU) No. 1981 of European Commission ( 4 kg/ha).

Results obtained during the presented trials underline the importance of well-planned strategies also with a deep knowledge of the mode of action of the products that are applied in crop protection according to what was also reported by other authors [58] "GreenGrapes" strategies that involved the integration and/or alternation of products based on plant extracts, yeast extracts, and seaweed extracts, to plant protection products gave a lower control efficacy $[23,36,41,47,65]$. This is in accordance with research studies [66], showing that the elicitors have a lower protection than conventional pesticides.

Despite this aspect, it should be emphasized that the severity of the disease both on the leaves and on the clusters remained very low in all three years, guaranteeing the quality of production without affecting production amount. Only in 2020 in the organic production with copper reduction did the severity reach significantly higher values.

The greater effectiveness of synthetic fungicides is clearly shown examining, as an example, the disease development in 2018, showing a disease incidence increase occurring after periods of high infection risk: inthe treatments managed with integrated control and fungicide reduction (IPM-GG), there were three periods of secondary infections risk, during which the official interval of efficacious protection by the treatments was no longer active: between 20 May and 27 May; between 09 June and 12 June and between 04 July and 23 July (the last one with 9 days at infection risk). In the first two periods, the residual effect of the interaction among the previous sprays (contact, systemic, and translaminar penetration) 
kept the incidence of the disease low, probably due to their interaction as reported in $[67,68]$, despite their official efficacy interval had expired.

Employment of supporting substances (seaweed extracts, hydrolyzed protein on yeast extracts) usually does not improve vine production, TSS, or total acidity, as reported by on cv Carmene [69,70], on cv Sangiovese [71,72], on cv Solaris and Regent [73], on cv Narince, and on cv Merlot [74]. On the other hand, beneficial effects are principally reported for antioxidant components on grapevines or other species [71,75-78].

We could conclude that the treatments carried out in 2018 on 27 June, 09 July, and 19 July including only elicitors, i.e., natural products with eliciting activity [79], failed to contain the attack of the pathogen. The monitoring carried out on 24 July showed a significant increase in the incidence of the disease, which stood at $43.5 \%$.

The pressure of the pathogen also plays a key role in the effectiveness of these type of treatments. During the three years of trials, it was possible to highlight how there is a threshold beyond which it is the natural plant defence action, even if supported by elicitors, which is able to control the epidemic. To confirm this, we can consider the disease development in 2019, when at the end of the growth season the incidence of the disease was very low in all the treatments, thanks to the low pressure of the pathogen [41].

As we know, the products with defense induction activity cannot simply replace the products with a direct antifungal activity even if they can often show a partial activity of this type $[41,64,80]$. In any case, as shown in this work, they can support the defense reaction of plants at a low disease pressure or improve the efficacy of plant protection products at a higher disease pressure.

Finally, it must be underlined that employment of supporting substances on IPM and ORG management allowed to maintain the same productivity (no differences for $p<0.05$ ) and grapes with the same (TSS, total anthocyanins) or better quality (total acidity).

\section{Conclusions}

This research work was focused on reduction in chemicals in the downy mildew control. Nevertheless, in the three years of trials infections by botrytis and powdery mildew agents were also surveyed and, as stated above, no infection by the two pathogens was ever recorded, even in the strong reduction treatments. This may be due to the characteristics of the two pathogens that are particularly sensitive to the resistance reaction induced in the plant (more actively sensitive than usually reported in the plant reaction to downy mildew).

The overall results of the three-year study indicate that disease management protocols based solely on the use of resistance-inducing substances do not appear to ensure effective protection against downy mildew infections. In actual fact, when the environmental conditions were favorable to the disease for several days (high pressure of the disease according to DSS), the treatments based on defense support products did not guarantee the protection of the crop compared with the IPM treatments.

A careful retrospective analysis of the infection risk graphs originated by the model over the three years of experimentation made it possible to identify the critical periods for the use of defense support products. In particular, in 2018 and 2020, years particularly favorable to the development of downy mildew, in periods of high disease pressure, there was the greatest increase in the incidence of downy mildew in GG treatment, coinciding with treatments with defense support products.

This highlights the need to act on the pathogen under certain environmental conditions, integrate resistance-inducing products to a copper-based strategy or a classic IPM strategy. Proper interpretation of the DSS can ensure sustainable defence and savings in the amount of pesticide use reduction.

In seasons that are climatically unfavorable to the development and spread of downy mildew such as in 2019, the amount of fungicides necessary for the defense of the vineyard can be significantly reduced in the context of both integrated and organic pest management. The correct interpretation of the risk provided by the DSS and the knowledge of the characteristics of the products used are essential for the reduction in fungicides. It must 
always be kept in mind that defense support products have an action on the plant, but not on the pathogen.

The use of fungicides is now a proven practice in viticulture thanks to low costs and a greater guarantee of effectiveness compared with new substances such as elicitors. Today, however, the greater sensitivity of consumers to organic farming and the rules that regulate it, push towards testing and challenging new products with a low environmental impact.

Supplementary Materials: The following are available online at https: / www.mdpi.com/article / 10.3390/agronomy12020392/s1, Tables S1-S3: Climate trend in 2018-2019-2020. Weeekly data from Vite.net Horta S.r.l.

Author Contributions: Conceptualization R.P. and L.M.; methodology R.P., L.M. and G.C.; software G.C., W.A.P.; validation R.P., M.E.M.D. and L.M.; investigation R.P., W.A.P., P.V., A.P., A.C. and G.C.; writing-original draft preparation W.A.P., A.C. and G.C.; writing-review and editing, R.P., P.S. and L.M.; supervision, R.P., P.S. and L.M.; funding acquisition P.S. All authors have read and agreed to the published version of the manuscript.

Funding: This research was funded by LIFE EU Life Green Grapes Project "New approaches for protection in a modern sustainable viticulture: from nursery to harvesting", grant number "LIFE16 $\mathrm{ENV} / \mathrm{IT} / 000566,2017 "$.

Institutional Review Board Statement: Not applicable.

Informed Consent Statement: Not applicable.

Data Availability Statement: Not applicable.

Acknowledgments: The authors are thankful to the farm "Castello di Gabbiano-Beringer Blass Italia" (San Casciano in Val di Pesa, Florence, Italy) for providing vineyards, Fabio Burroni and Marco Pierucci for technical support.

Conflicts of Interest: The authors declare no conflict of interest. The funders had no role in the design of the study; in the collection, analyses, or interpretation of data; in the writing of the manuscript, or in the decision to publish the results.

\section{References}

1. FAOSTAT. Food and Agriculture Organization of the United Nations. 2020. Available online: http://www.fao.org/faostat/en/ \#data/QC (accessed on 3 December 2021).

2. Cirillo, C.; Arena, C.; Rouphael, Y.; Caputo, R.; Amitrano, C.; Petracca, F.; De Francesco, S.; Vitale, E.; Erbaggio, A.; Bonfante, A.; et al. Counteracting the Negative Effects of Copper Limitations Through the Biostimulatory Action of a Tropical Plant Extract in Grapevine Under Pedo-Climatic Constraints. Front. Environ. Sci. 2021, 9, 76. [CrossRef]

3. Damalas, C.A. Safe Food Production with Minimum and Judicious Use of Pesticides. In Food Safety; Selamat, J., Iqbal, S., Eds.; Springer: Cham, Switzerland, 2016; pp. 43-55.

4. ISTAT-Istituto Nazionale di Statistica-Banca Dati. Available online: http://dati.istat.it/ (accessed on 3 December 2021).

5. Provost, C.; Pedneault, K. The organic vineyard as a balanced ecosystem: Improved organic grape management and impacts on wine quality. Sci. Hortic. 2016, 208, 43-56. [CrossRef]

6. Mackie, K.; Müller, T.; Kandeler, E. Remediation of copper in vineyards-A mini review. Environ. Pollut. 2012, 167, 16-26. [CrossRef] [PubMed]

7. Brunetto, G.; Miotto, A.; Ceretta, C.A.; Schmitt, D.E.; Heinzen, J.; Moraes, M.P.; Canton, L.; Tiecher, T.L.; Comin, J.J.; Girotto, E. Mobility of copper and zinc fractions in fungicide-amended vineyard sandy soils Arch. Agro. Soil Sci. 2014, 60, 609-624. [CrossRef]

8. Tiecher, T.L.; Tiecher, T.; Ceretta, C.A.; Ferreira, P.A.A.; Nicoloso, F.T.; Soriani, H.H.; Tassinari, A.; Paranhos, J.T.; De Conti, L.; Brunetto, G. Plant Physiology and Biochemistry Physiological and nutritional status of black oat (Avena strigosa Schreb.) grown in soil with interaction of high doses of copper and zinc. Plant Physiol. Biochem. 2016, 106, 253-263. [CrossRef] [PubMed]

9. Tiecher, T.L.; Tiecher, T.; Ceretta, C.A.; Ferreira, P.A.; Nicoloso, F.T.; Soriani, H.H.; De Conti, L.; Kulmann, M.S.D.S.; Schneider, R.O.; Brunetto, G. Tolerance and translocation of heavy metals in young grapevine (Vitis vinifera) grown in sandy acidic soil with interaction of high doses of copper and zinc. Sci. Hortic. 2017, 222, 203-212. [CrossRef]

10. Weng, L.; Temminghoff, E.J.M.; Lofts, S.; Tipping, E.; Van Riemsdijk, W.H. Complexation with Dissolved Organic Matter and Solubility Control of Heavy Metals in a Sandy Soil. Environ. Sci. Technol. 2002, 36, 4804-4810. [CrossRef]

11. Michaud, A.M.; Chappellaz, C.; Hinsinger, P. Copper phytotoxicity affects root elongation and iron nutrition in durum wheat (Triticum turgidum durum L.). Plant Soil 2008, 310, 151-165. [CrossRef] 
12. Lequeux, H.; Hermans, C.; Lutts, S.; Verbruggen, N. Plant Physiology and Biochemistry Response to copper excess in Arabidopsis thaliana, impact on the root system architecture; hormone distribution; lignin accumulation and mineral profile. Plant Physiol. Biochem. 2010, 48, 673-682. [CrossRef]

13. De Conti, L.; Ceretta, C.A.; Ferreira, P.A.; Lourenzi, C.R.; Girotto, E.; Lorensini, F.; Tiecher, T.L.; Marchezan, C.; Anchieta, M.G.; Brunetto, G. Soil solution concentrations and chemical species of copper and zinc in a soil with a history of pig slurry application and plant cultivation. Agric. Ecosyst. Environ. 2016, 216, 374-386. [CrossRef]

14. Cataldo, E.; Fucile, M.; Mattii, G.B. Biostimulants in Viticulture: A Sustainable Approach against Biotic and Abiotic Stresses. Plants 2022, 11, 162. [CrossRef] [PubMed]

15. Paoletti, M.; Sommaggio, D.; Favretto, M.; Petruzzelli, G.; Pezzarossa, B.; Barbafieri, M. Earthworms as useful bioindicators of agroecosystem sustainability in orchards and vineyards with different inputs. Appl. Soil Ecol. 1998, 10, 137-150. [CrossRef]

16. Pellegrini, A.; Prodorutti, D.; Frizzi, A.; Gessler, C.; Pertot, I. Development and evaluation of a warning model for the optimal use of copper in organic viticulture. J. Plant Pathol. 2010, 92, 43-55.

17. Ge, C.R.; Zhang, Q.C. Microbial community structure and enzyme activities in a sequence of copper-polluted soils. Pedosphere 2011, 21, 164-169. [CrossRef]

18. Mackie, K.A.; Muller, T.; Zikely, S.; Kandeler, E. Long-term copper application in an organic vineyard modifies spatial distribution of soil micro-organisms. Soil Biol. Biochem. 2013, 65, 245-253. [CrossRef]

19. Fagnano, M.; Agrelli, D.; Pascale, A.; Adamo, P.; Fiorentino, N.; Rocco, C.; Pepe, O.; Ventorino, V. Copper accumulation in agricultural soils: Risks for the food chain and soil microbial populations. Sci. Total Environ. 2020, 734, 139434. [CrossRef]

20. Karimi, B.; Cahurel, J.-Y.; Gontier, L.; Charlier, L.; Chovelon, M.; Mahé, H.; Ranjard, L. A meta-analysis of the ecotoxicological impact of viticultural practices on soil biodiversity. Environ. Chem. Lett. 2020, 18, 1947-1966. [CrossRef]

21. Pertot, I.; Delaiti, M.; Mescalchin, E.; Zini, A.; Forti, D. The Activity of New Formulations of Copper Solutions against Downy Mildew; Reduced Doses and Alternative Products to Copper Used in Organic Viticulture; Atti delle Giornate Fitopatologiche: Trento, Italy, 2002; Volume 2, pp. 7-11.

22. Matasci, C.L.; Gobbin, D.; Schärer, H.-J.; Tamm, L.; Gessler, C. Selection for fungicide resistance throughout a growing season in populations of Plasmopara Viticola. Eur. J. Plant Pathol. 2007, 120, 79-83. [CrossRef]

23. Dagostin, S.; Schärer, H.-J.; Pertot, I.; Tamm, L. Dagostin, S.; Schärer, H.J.; Pertot, I.; Tamm, L. Are there alternatives to copper for controlling grapevine downy mildew in organic viticulture? Crop Prot. 2011, 30, 776-788. [CrossRef]

24. Kullaj, E.; Shahini, S.; Varaku, S.; Çakalli, M. Evaluation of the efficacy for reducing copper use against downy mildew control in organic Mediterranean viticulture. Int. J. Pest Manag. 2016, 63, 3-9. [CrossRef]

25. Pertot, I.; Caffi, T.; Rossi, V.; Mugnai, L.; Hoffmann, C.; Grando, M.; Gary, C.; Lafond, D.; Duso, C.; Thiery, D.; et al. A critical review of plant protection tools for reducing pesticide use on grapevine and new perspectives for the implementation of IPM in viticulture. Crop Prot. 2017, 97, 70-84. [CrossRef]

26. Hildebrandt, A.; Guillamón, M.; Lacorte, S.; Tauler, R.; Barceló, D. Impact of pesticides used in agriculture and vineyards to surface and groundwater quality (North Spain). Water Res. 2008, 42, 3315-3326. [CrossRef]

27. Komárek, M.; Čadková, E.; Chrastný, V.; Bordas, F.; Bollinger, J.-C. Contamination of vineyard soils with fungicides: A review of environmental and toxicological aspects. Environ. Int. 2010, 36, 138-151. [CrossRef]

28. Nash, M.A.; Hoffmann, A.A.; Thomson, L.J. Identifying signature of chemical applications on indigenous and invasive nontarget arthropod communities in vineyards. Ecol. Appl. 2010, 20, 1693-1703. [CrossRef]

29. Marinho, M.D.C.; Diogo, B.S.; Lage, O.M.; Antunes, S.C. Ecotoxicological evaluation of fungicides used in viticulture in non-target organisms. Environ. Sci. Pollut. Res. 2020, 27, 43958-43969. [CrossRef]

30. Leroux, P.; Fritz, R.; Debieu, D.; Albertini, C.; Lanen, C.; Bach, J.; Gredt, M.; Chapeland, F. Mechanisms of resistance to fun-gicides in field strains of Botrytis cinerea. Pest Manag. Sci. 2002, 58, 876-888. [CrossRef] [PubMed]

31. Savocchia, S.; Stummer, B.E.; Wicks, T.J.; Van Heeswijck, R.; Scott, E.S. Reduced sensitivity of Uncinula necator to sterol demethylation inhibiting fungicides in southern Australian vineyards. Aust. Plant Pathol. 2004, 33, 465-473. [CrossRef]

32. D'Amico, M.; Di Vita, G.; Monaco, L. Exploring environmental consciousness and consumer preferences for organic wines without sulphites. J. Clean. Prod. 2016, 120, 64-71. [CrossRef]

33. Viana, R.E.; López-Alfaro, I.; López, R.; Santamaría, P.; Gutiérrez, A.R.; González-Arenzana, L. Impact of Chemical and Biological Fungicides Applied to Grapevine on Grape Biofilm, Must, and Wine Microbial Diversity. Front. Microbiol. 2018, 9, 59. [CrossRef]

34. Jacometti, M.A.; Wratten, S.D.; Walter, M.; Aust, J. Review, Alternatives to synthetic fungicides for Botrytis cinerea management in vineyards. Grape Wine Res. 2010, 16, 154-172. [CrossRef]

35. Gadoury, D.M.; Pearson, R.C. Ascocarp dehiscence and ascospore discharge in Uncinula necator. Phytopathology 1990, 80, 93-401. [CrossRef]

36. La Torre, A.; Righi, L.; Iovino, V.; Battaglia, V. Evaluation of copper alternative products to control grape downy mildew in organic farming. J. Plant Pathol. 2019, 101, 1005-1012. [CrossRef]

37. Benìtez, T.; Rincòn, A.M.; Codòn, A.C. Biocontrol mechanisms of Trichoderma strains. International Microbiology 2004, 7, 249-260.

38. Kauss, H.; Theisinger-Hinkel, E.; Mindermann, R.; Conrath, U. Dichloroisonicotinic and salicylic acid, inducers of systemic acquired resistance, enhance fungal elicitor responses in parsley cells. Plant J. 1992, 2, 655-660. [CrossRef]

39. Walters, D.; Walsh, D.; Newton, A.; Lyon, G. Induced Resistance for Plant Disease Control: Maximizing the Efficacy of Resistance Elicitors. Phytopathology 2005, 95, 1368-1373. [CrossRef] 
40. Burketova, L.; Trda, L.; Otto, P.G.; Valentova, O. Bio-based resistance inducers for sustainable plant protection against pathogens. Biotechn. Adv. 2015, 33, 994-1004. [CrossRef]

41. Pertot, I.; Giovannini, O.; Benanchi, M.; Caffi, T.; Rossi, V.; Mugnai, L. Combining biocontrol agents with different mechanisms of action in a strategy to control Botrytis cinerea on grapevine. Crop Prot. 2017, 97, 85-93. [CrossRef]

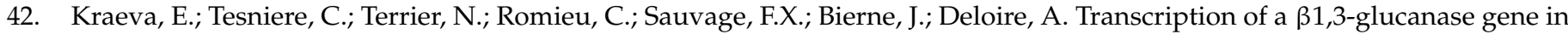
grape berries in a late developmental period, or earlier after wounding treatments. Vitis 1998, 37,107-111.

43. Renault, A.S.; Deloire, A.; Bierne, J. Pathogenesis-Related proteins induced in grapevine by salicylic acid and Botrytis cinerea Vitis 1996, 35, 49-52.

44. Schweikert, C.; Mildner, M.; Vollrath, C.; Kassemeyer Hanns-Heinz, A.H. Systems for testing the efficacy of biofungicides and resistance inducers against downy mildew (REPCO Project). In Organic Eprint; Joint Organic Congress: Odense, Denmark, 2006.

45. Harm, A.; Kassemeyer, H.-H.; Seibicke, T.; Regner, F. Evaluation of Chemical and Natural Resistance Inducers against Downy Mildew (Plasmopara viticola) in Grapevine. Am. J. Enol. Vitic. 2011, 62, 184-192. [CrossRef]

46. Reuveni, M.; Zahavi, T.; Cohen, Y. Controlling downy mildew (Plasmopara viticola) in field-grown grapevine with $\beta$-aminobutyric acid (BABA). Phytoparasitica 2001, 29, 125-133. [CrossRef]

47. Pinto, K.M.S.; Nascimento, L.C.D.; Gomes, E.C.D.S.; Da Silva, H.F.; Miranda, J.D.R. Efficiency of resistance elicitors in the management of grapevine downy mildew Plasmopara viticola: Epidemiological, biochemical and economic aspects. Eur. J. Plant Pathol. 2012, 134, 745-754. [CrossRef]

48. Mancuso, S.; Azzarello, E.; Mugnai, S.; Briand, X. Marine Bioactive Substances (IPA Extract) Improve Foliar Ion Uptake and Water Stress Tolerance in Potted «Vitis vinifera» Plants. Adv. Hort. Sci. 2006, 20, 156-161.

49. Calvo, P.; Nelson, L.; Kloepper, J.W. Agricultural uses of plant biostimulants. Plant Soil 2014, 383, 3-41. [CrossRef]

50. Brown, P.D.; Morra, M.J. Control of soilborne plant pests using glucosinolate-containing plants. Adv. Agron. 1997, 61, 167-231.

51. Du Jardin, P. Plant biostimulants: Definition, concept, main categories and regulation. Sci. Hortic. 2015, 196, 3-14. [CrossRef]

52. Kuflik, T.; Prodorutti, D.; Frizzi, A.; Gafni, Y.; Simon, S.; Pertot, I. Optimization of copper treatments in organic viticulture by using a web-based decision support system. Comput. Electron. Agric. 2009, 68, 36-43. [CrossRef]

53. Rossi, V.; Caffi, T.; Legler, S.E.; Carotenuto, E.; Bigot, G. Large-scale application of a web-based Decision Support System for sustainable viticulture. In Proceedings of the IOBC/WPRS Working Group "Integrated protection and production in Viticulture", Ascona, Switzerland, 13-17 October 2013; Volume 105, pp. 129-136.

54. Pérez-Expósito, J.P.; Fernández-Caramés, T.M.; Fraga-Lamas, P.; Castedo, L. VineSens: An Eco-Smart Decision-Support Viticulture System. Sensors 2017, 17, 465. [CrossRef]

55. Landis, D.A.; Wratten, S.D.; Gurr, G.M. Habitat Management to Conserve Natural Enemies of Arthropod Pests in Agriculture. Annu. Rev. Entomol. 2000, 45, 175-201. [CrossRef]

56. Dane, K.M.; Hogg, B.N.; Wilson, H.; Yokota, G. Native grass ground cover provides multiple ecological services in Californian vineyards. J. Appl. Ecol. 2018, 55, 2473-2483. [CrossRef]

57. Cherr, C.M.; Scholberg, J.M.S.; McSorley, R. Green Manure Approaches to Crop Production, a synthesis. Agron. J. 2006, 98, 302-319. [CrossRef]

58. Coll, P.; Le Cadre, E.; Blanchart, E.; Hinsinger, P.; Villenave, C. Organic viticulture and soil quality: A long-term study in Southern France. Appl. Soil Ecol. 2011, 50, 37-44. [CrossRef]

59. Rotaru, L.; Stoleru, V.; Mustea, M. Fertilization with green manure on Chasselas Doré grape vine as an alternative for sustainable viticulture. J. Food Agric. Environ. 2011, 9, 236-243.

60. Longa, C.; Nicola, L.; Antonielli, L.; Mescalchin, E.; Zanzotti, R.; Turco, E.; Pertot, I. Soil microbiota respond to green manure in organic vineyards. J. Appl. Microbiol. 2017, 123, 1547-1560. [CrossRef] [PubMed]

61. Zanzotti, R.; Mescalchin, E. Green manure effects on inorganic nitrogen dynamics in soil and its accumulation in grape must. BIO Web Conf. 2019, 13, 04010. [CrossRef]

62. European and Mediterranean Plant Protection Organisation. EPPO Standards for the Efficacy Evaluation of Plant Protection Products. Available online: https://www.eppo.int/RESOURCES/eppo_standards/pp1_list;PP1/31(1) (accessed on 30 September 2017).

63. Saint-Cricq de Gaulejac, N.; Vivas, N.; Glories, Y. Maturation phénolique des raisins rouges. Relation avec la qualité des vins. Comparaison des cépages merlot et tempranillo. Prog. Agric. Et Viticole 1998, 115, 306-318.

64. Caffi, T.; Rossi, V. Fungicide models are key components of multiple modelling approaches for decision-making in crop protection. Phytopathol. Mediterr. 2018, 57, 153-169.

65. Krzyzaniak, Y.; Trouvelot, S.; Negrel, J.; Cluzet, S.; Valls, J.; Richard, T.; Bougaud, A.; Jacquens, L.; Klinguer, A.; Chiltz, A.; et al. A plant extract acts both as a resistance inducer and an oomycide against grapevine downy mildew. Front. Plant Sci. $2018,9,1085$. [CrossRef]

66. Delaunois, B.; Farace, G.; Jeandet, P.; Clément, C.; Baillieul, F.; Dorey, S.; Cordelier, S. Elicitors as alternative strategy to pesticides in grapevine? Current knowledge on their mode of action from controlled conditions to vineyard. Environ. Sci. Pollut. Res. 2013, 21, 4837-4846. [CrossRef]

67. Bleyer, G.; Huber, B.; Steinmetz, V.; Kassemeyer, H.H. Growth-models, a tool to define spray intervals against downy mildew (Plasmopara viticola). IOBC WPRS BULLETIN 2003, 26, 7-12. 
68. Bleyer, G.; Lösch, F.; Schumacher, S.; Fuchs, R. Together for the Better: Improvement of a Model Based Strategy for Grapevine Downy Mildew Control by Addition of Potassium Phosphonates. Plants 2020, 9, 710. [CrossRef]

69. Gutiérrez-Gamboa, G.; Garde-Cerdán, T.; Costa, B.S.-D.; Moreno-Simunovic, Y. Strategies for the improvement of fruit set in Vitis vinifera L. cv. 'Carménère' through different foliar biostimulants in two different locations. Ciência E Técnica Vitivinícola 2018, 33, 177-183. [CrossRef]

70. Frioni, T.; Sabbatini, P.; Tombesi, S.; Norrie, J.; Poni, S.; Gatti, M.; Palliotti, A. Effects of a biostimulant derived from the brown seaweed Ascophyllum nodosum on ripening dynamics and fruit quality of grapevines. Sci. Hortic. 2018, 232, 97-106. [CrossRef]

71. Salvi, L.; Brunetti, C.; Cataldo, E.; Niccolai, A.; Centritto, M.; Ferrini, F.; Mattii, G.B. Effects of Aschophyllum nodosum extracts on Vitis vinifera: Consequences on plant physiology, grape quality and secondary metabolism. Plant Physiol. Biochem. 2019, 139, 21-32. [CrossRef] [PubMed]

72. Lisek, J.; Sas-Paszt, L.; Derkowska, E.; Mrowicki, T.; Przybył, M.; Frąc, M. Growth, yelding and healthiness of grapevine cultivars "Solaris" and "Regent" in response to fertilizers and biostimulants. J. Hortic. Res. 2016, 24, 49-60. [CrossRef]

73. Sabir, A.; Yazar, K.; Sabir, F.; Kara, Z.; Yazici, M.A.; Goksu, N. Vine growth, yield, berry quality attributes and leaf nutrient content of grapevines as influenced by seaweed extract (Ascophyllum nodosum) and nanosize fertilizer pulverizations. Sci. Hortic. 2014, 175, 1-8. [CrossRef]

74. Taskos, D.; Stamatiadis, S.; Yvin, J.-C.; Jamois, F. Effects of an Ascophyllum nodosum (L.) Le Jol. extract on grapevine yield and berry composition of a Merlot vineyard. Sci. Hortic. 2019, 250, 27-32. [CrossRef]

75. Basile, B.; Rouphael, Y.; Colla, G.; Soppelsa, S.; Andreotti, C. Appraisal of emerging crop management opportunities in fruit trees, grapevines and berry crops facilitated by the application of biostimulants. Sci. Hortic. 2020, 267, 109330. [CrossRef]

76. Boselli, M.; Bahouaoui, M.A.; Lachhab, N.; Sanzani, S.M.; Ferrara, G.; Ippolito, A. Protein hydrolysates effects on grapevine (Vitis vinifera L., cv. Corvina) performance and water stress tolerance. Sci. Hortic. 2019, 258, 108784. [CrossRef]

77. Soppelsa, S.; Kelder, M.; Casera, C.; Bassi, M.; Robatscher, P.; Matteazzi, A.; Andreotti, C. Foliar application of biostimulants promote growth, yeld and fruit quality of strawberry plants grown under nutrient limitation. Agronomy 2019, 9, 483. [CrossRef]

78. Colla, G.; Nardi, S.; Cardarelli, M.; Ertani, A.; Lucini, L.; Canaguier, R.; Rouphael, Y. Protein hydrolysates as biostimulants in horticulture. Sci. Hortic. 2015, 196, 28-38. [CrossRef]

79. La Torre, A.; Talocci, S.; Spera, G.; Valori, R. Control of downy mildew on grapes in organic viticulture. Commun. Agric. Appl. Biol. Sci. 2008, 73, 169-178. [PubMed]

80. Feliziani, E.; Santini, M.; Landi, L.; Romanazzi, G. Pre- and postharvest treatment with alternatives to synthetic fungicides to control postharvest decay of sweet cherry. Postharvest Biol. Technol. 2013, 78, 133-138. [CrossRef] 